\title{
EXAMPLE OF USING LEAN MANUFACTURING \\ sciendo TOOLS IN ASSESSING AND IMPROVING THE PROCESS OF CAR ARM REST PRODUCTION
}

doi:10.2478/mape-2018-0028

Date of submission of the article to the Editor: 05/2018

Date of acceptance of the article by the Editor: 07/2018

MAPE 2018, volume 1, issue 1, pp. 217-222

PhD., Eng. Michał Molenda

Silesian University of Technology, Poland

MSc., Eng. Aneta Biernot

Automotive Company, Poland

Doc., Ing. Helena Cierna, PhD.

Technical University in Zvolen, Slovak Republic

\begin{abstract}
The paper deals with the use of Lean Manufacturing tools in improving the production process of car arm rests in a car manufacturing company in Poland. The article describes the original condition of a single production process of assembling ready pieces to produce car arm rests. The original condition was assessed and described with the use of some basic Lean indicators and value stream mapping. The aforementioned tools allowed to assess the process condition and to identify the organizational issues and their sources. It also enabled to reorganize the process and increase its efficiency. The further part of the article describes the results of improvement actions. The process assessment was held and improvements introduced in the first quarter of 2018 .
\end{abstract}

Keywords: lean management, lean manufacturing, lean production.

\section{INTRODUCTION}

Constant increase of both global competition and clients' request level force enterprises to maximize their efficiency. The phenomenon is especially characteristic for automobile businesses. Their success depends not only on car models they offer but first of all on the efficient production systems they have. Because of their massive character, the system efficiency is based on the use of such resources as people, machines, materials, energy and time that directly influence production cost. Lean Management is a methodology that deals with improving business processes. It focuses on identifying and eliminating all possible kinds of waste. The article describes an example of using Lean Manufacturing to analyze and improve the results of car parts production process such as arm rests in a manufacturing company. The article describes the original condition of a manufacturing company and the results of the research using operational indicators of the assembly process to be improved. The research was held in the first quarter of 2018 and its results allowed to identify the organizational issues and their sources. Below will you find the description of improvement actions and the results obtained.

\section{LEAN TOOLS IN IMPROVING PRODUCTION PROCESS}

Nowadays it is hard to imagine a successful manufacturing company without Lean Tools. Their role has been clearly stated in many studies and manuals (Książek and Ligarski, 2016). Lean Management is a company management system aimed at high efficiency in all possible aspects. Lean Manufacturing applies to production processes. The term was coined in 1990 (Womack at al., 1990). The authors of 'The Machine That Changed the World' compared the 
disbursals and results in Japanese, American and European companies. The leader of the analysis in question was the Japanese Toyota Motor Production and its Toyota Production System which was the first slimmed and skimmed production system later called Lean Manufacturing. It became the model of perfection. Today the concept of Lean Manufacturing is a global assessment and improvement tool for business processes. A lot of studies and manuals deal with the idea of Lean Manufacturing. It is used in almost all branches such as automotive (Midor, 2017), mining (Stecuła et al., 2017) and metallurgical industry (Wolniak at al., 2013). Le $\square \mathrm{n} M \square$ nuf $\square$ cturing is not limited to $\square$ cert $\square$ in kind of processes; the Tools c $\square \mathrm{n}$ be used to both assess and improve the processes of machines maintenance (Zasadzeń, 2015) and the logistics ones, to name a few (Pałucha, 2012). It is not surprising that Lean Tools are also used in IT solution systems as a support tool (Wojtaszak and Biały, 2013).

The main concept of Lean methodology is to eliminate any kind of waste (Rother and Shook 1998). It requires to define the client's values, i.e. all activities the client is ready to pay for. This kind of activities are called value-adding activities and are determined as VA (Value Added). All essential activities in a process that have no added value in a given process are determined as $\mathrm{R}$ (required). The last group of activities includes the redundant ones with no added value such $\square$ s downtime; they $\square$ re determined $\square$ s NVA (non-v $\square$ lue $\square$ dding); they should be eliminated while all the other activities should be improved with the use of Lean Tools to create materials and raw materials free flows. Lean methodology considers production process stopping and artificial grouping activities a waste to be eliminated.

In order to analyze and improve production processes and their operations, the following indicators have been used in this study:

- Takt Time (T/T). Time within which a single piece of product should be produced. The indicator is calculated by the following formula (Velacio.com, 2018):

$$
T / T=\frac{\text { Production Time Available }}{\text { Customer Demand }}
$$

- Cycle Time (CT). Time between a product and the one following it leaves a given operation in a process (Rother and Shook 1998).

- Line Balance Rate (LBR). Line Balance Rate for n-operations calculated as follows (Łopatowska and Jaroński 2016) :

$$
L B R=\frac{\sum_{i=1}^{n} C T_{i}}{T / T * S T}
$$

where $S T$ is a number of stands/operators in a process.

- $\mathrm{HC}$ describes the number of operators necessary in a given process. The formula is calculated as follows (Łopatowska and Jaroński, 2016):

$$
H C=\frac{\sum_{i=1}^{n} C T_{i}}{T / T * W O O}
$$

where $W O O$ is an indicator of a single operator workload and amounts to $0.85-0.95$.

\section{DIAGNOSIS OF THE ARMREST ASSEMBLY PROCESS}

A process to be improved is one of the processes of overproduction of car arm rests. The process consists of assembling a product from elements that have been previously cut and sewed. Ready car arm rests are produced for a multinational automotive corporation. The assembly process has to meet high quality and efficiency standards. To improve the efficiency of the production, the company management decided to assess and reorganize the assembly process. Lean Tools enabled satisfying results in process efficiency to be obtained.

In order to assess and improve the process in question, the following actions have been taken: observing how the production line works in the assembly process, assessing how the process is organized, collecting data and analyzing the indicators, value stream mapping (VSM), assessing the original condition of the assembly process, setting solutions to improve selected processes, reorganizing the process and introducing changes, final assessment.

The basic criterion assumed to assess the assembly process was the Takt Time (T/T) established on the basis of the client's demand and adopted work organization in the company. 
Takt Time was calculated as $40 \mathrm{sec}$. It meant that in order to organize the assembly process correctly, a single product produced for a client should be finished in $40 \mathrm{sec}$.

The observing of the process enabled to identify the activities in the process. The process consists of ten basic operations handled in ten stands by ten operators. The first operation in the process is assembling a cup holder in assembly foam. The next step is assembling the foam element in cover and forming. Both operations are demanding in terms of precision because of the expected visual effects. The operator has to focus on burring all the seams and edges, closing the zip and profiling. Having completed that an arm rest is a ready product. The last step consists of assembling the masking frame that allows to hide the cup holder. Having completed the quality control, the product is five-packed and can be shipped to client.

\section{ORIGINAL CONDITIONS RESULTS AND IMPROVEMENT ACTIONS}

The detailed analysis of the operation time of the assembly process has been made on the basis of a working day that was filmed with Video TimePro software. Table 1 shows the results of value added flow examination for all the operations in the assembly process. It also presents the results of basic activities identification, their duration and waste time analysis.

Table 1

Results of original condition analysis of assembly process

\begin{tabular}{|c|c|c|c|c|c|c|}
\hline $\begin{array}{l}\frac{5}{\frac{0}{\pi}} \\
\frac{0}{ \pm} \\
\frac{0}{0}\end{array}$ & Basic activities & Type & $\begin{array}{l}\text { Duration } \\
\text { of basic } \\
\text { activities } \\
\text { [sec.] }\end{array}$ & $\begin{array}{c}\text { Duration of } \\
\text { operation } \\
\text { [sec.] }\end{array}$ & $\begin{array}{c}\text { Cycle time } \\
\mathrm{CT}_{\mathrm{i}}=\mathrm{VA}+\mathrm{R} \\
\text { [sec.] }\end{array}$ & $\begin{array}{l}\text { NVA } \\
\text { [sec.] }\end{array}$ \\
\hline \multirow{2}{*}{1} & collecting foams (3 pcs) & VA & 12.87 & \multirow{2}{*}{19.76} & \multirow{2}{*}{19.76} & \multirow{2}{*}{-} \\
\hline & mounting the cup holder to the foam & VA & 6.89 & & & \\
\hline \multirow{4}{*}{2} & mounting the foam to the vacuum & VA & 6.59 & \multirow{4}{*}{54.46} & \multirow{4}{*}{26.22} & \multirow{4}{*}{28.24} \\
\hline & mounting the cover on foam & VA & 14.71 & & & \\
\hline & compression of the cover & VA & 4.92 & & & \\
\hline & waiting & NVA & 28.24 & & & \\
\hline \multirow{4}{*}{3} & profiling the upper edges & $\mathrm{R}$ & 14.57 & \multirow{4}{*}{44.16} & \multirow{4}{*}{36.03} & \multirow{4}{*}{8.13} \\
\hline & profiling the bottom edges & $\mathrm{R}$ & 11.25 & & & \\
\hline & fastening of pins & VA & 10.21 & & & \\
\hline & waiting & NVA & 8.13 & & & \\
\hline \multirow{3}{*}{4} & profiling the side edges & $\mathrm{R}$ & 17.36 & \multirow{3}{*}{43.71} & \multirow{3}{*}{33.77} & \multirow{3}{*}{9.94} \\
\hline & fastening of central slats & VA & 16.41 & & & \\
\hline & waiting & NVA & 9.94 & & & \\
\hline \multirow{5}{*}{5} & fastening of side slats & VA & 11.00 & \multirow{5}{*}{54.2} & \multirow{5}{*}{40.85} & \multirow{5}{*}{13.35} \\
\hline & profiling the lower corners & $\mathrm{R}$ & 7.00 & & & \\
\hline & visual inspection & $\mathrm{R}$ & 11.37 & & & \\
\hline & waiting & NVA & 13.35 & & & \\
\hline & profiling the bottom edges & $\mathrm{R}$ & 11.48 & & & \\
\hline \multirow{3}{*}{6} & hiding the zipper & VA & 25.39 & \multirow{3}{*}{58.98} & \multirow{3}{*}{40.45} & \multirow{3}{*}{18.53} \\
\hline & waiting & NVA & 18.53 & & & \\
\hline & fastening the zipper & VA & 15.06 & & & \\
\hline \multirow{4}{*}{7} & ironing & $\mathrm{R}$ & 17.83 & \multirow{4}{*}{62.69} & \multirow{4}{*}{52.74} & \\
\hline & thread hiding & $\mathrm{R}$ & 21.45 & & & 005 \\
\hline & visual inspection & $\mathrm{R}$ & 13.46 & & & 9.95 \\
\hline & waiting & NVA & 9.95 & & & \\
\hline & installation of the armrest in the base & VA & 6.48 & & & \\
\hline 8 & masking frame assembly in the armrest & VA & 4.98 & 19.78 & 19.78 & - \\
\hline & cupholder flap quality control & $\mathrm{R}$ & 8.32 & & & \\
\hline 9 & final quality control & $\mathrm{R}$ & 13.01 & 3659 & 1301 & 2358 \\
\hline 9 & waiting & NVA & 23.58 & 36.59 & 13.01 & 23.58 \\
\hline & packing & VA & 10.21 & & & \\
\hline & placing the foam & VA & 5.05 & & & \\
\hline 10 & labeling & VA & 8.68 & 59.07 & 36.85 & 22.22 \\
\hline & waiting & NVA & 22.22 & & & \\
\hline & packing 5 items into the container & VA & 12.91 & & & \\
\hline & & & & 453.4 & 319.5 & 134 \\
\hline & & & & $100 \%$ & $70 \%$ & $30 \%$ \\
\hline
\end{tabular}


On the basis of collected data, having assumed $40 \mathrm{sec}$. Takt Time (T/T) and operator workload indicator 0.85 (WOO), $\mathrm{b} \square$ sic process $\mathrm{p} \square$ r $\square$ meters such $\square \mathrm{s} \mathrm{HC} \square$ nd LBBR $\mathrm{h} \square$ ve been c $\square$ lcul $\square$ ted; they are shown in Table 2.

Table 2

Original assembly process parameters.

\begin{tabular}{|l|l|}
\hline Parameter & Calculations \\
\hline $\mathrm{T} / \mathrm{T}$ & $40 \mathrm{~s}$. \\
\hline $\mathrm{HC}$ & $319.5 \mathrm{~s} /(40 \mathrm{~s} * 0.85)=9.4(\sim 10)$ \\
\hline LBR & $(319.5 \mathrm{~s} /(40 \mathrm{~s} * 10))^{*} 100 \%=80 \%$ \\
\hline
\end{tabular}

The results of the process analysis proved it was wrongly balanced. The time of most operations was major than the adopted production takt. Operations 1, 8 and 9 were the only ones that lasted less than assumed $40 \mathrm{sec}$. Unfortunately, almost $30 \%$ of the assembly operations time was dedicated to non-value adding activities. The LBR parameter of $80 \%$ indicates the improvement margin of $20 \%$.

The main goal of the improvement process was to eliminate non-value adding activities and to balance the number of operators. The improvement was oriented towards introducing constant material flow, i.e. one piece flow, which consists of passing single products at one time to the next stand. It eliminates waiting time considered the biggest non-value adding activity in the analyzed process.

\section{RESULTS OBTAINED AFTER PROCESS REORGANIZATION}

Results of assembly process analysis enabled to determine organizational changes. As a result it was necessary to:

- introduce a constant single piece flow,

- reorganize the process and divide it in 5 main operations containing all elementary activities,

- eliminate inter operational quality control thanks to introduced work standardization.

Figure 1 presents general results of the process reorganization in the form of the Yamazumi chart.

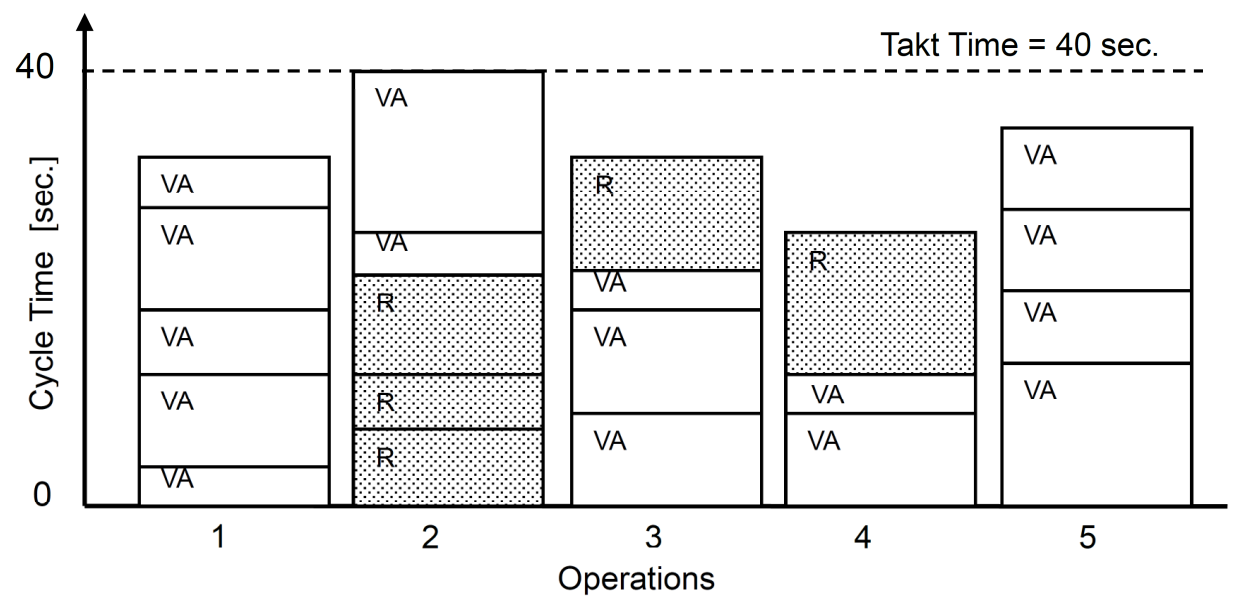

Fig 1. Yamazumi chart for present assembly process

The table 3 shows the reorganized assembly process and detail time analysis. 
Table 3

Results of assembly process analysis as is

\begin{tabular}{|c|c|c|c|c|}
\hline 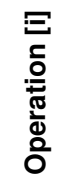 & Basic activities & Type & $\begin{array}{c}\text { Duration of } \\
\text { basic } \\
\text { activities } \\
\text { [sec.] }\end{array}$ & $\begin{array}{c}\text { Cycle time } \\
\mathrm{CT}_{\mathrm{i}}=\mathrm{VA}+\mathrm{R} \\
\text { [sec.] }\end{array}$ \\
\hline \multirow[t]{5}{*}{1} & collecting foams (3 pcs) & VA & 2.64 & \multirow{5}{*}{37.14} \\
\hline & mounting the cup holder to the foam & VA & 10.06 & \\
\hline & mounting the foam to the vacuum & VA & 6.50 & \\
\hline & mounting the cover on foam & VA & 13.12 & \\
\hline & compression of the cover & VA & 4.82 & \\
\hline \multirow[t]{5}{*}{2} & profiling the side edges & $\mathrm{R}$ & 7.22 & \multirow{5}{*}{39.86} \\
\hline & profiling the upper edges & $\mathrm{R}$ & 5.72 & \\
\hline & profiling the bottom edges & $\mathrm{R}$ & 10.18 & \\
\hline & fastening of pins & VA & 3.25 & \\
\hline & fastening of central slats & VA & 13.49 & \\
\hline \multirow[t]{4}{*}{3} & fastening the zipper & VA & 8.75 & \multirow{4}{*}{33.08} \\
\hline & hiding the zipper & VA & 10.60 & \\
\hline & fastening of pins & VA & 3.53 & \\
\hline & ironing & $\mathrm{R}$ & 10.20 & \\
\hline \multirow[t]{3}{*}{4} & masking frame assembly in the armrest & VA & 8.365 & \multirow{3}{*}{25.265} \\
\hline & cupholder flap quality control & VA & 3.82 & \\
\hline & final quality control & $\mathrm{R}$ & 13.08 & \\
\hline \multirow[t]{4}{*}{5} & packing & VA & 12.39 & \multirow{4}{*}{34.99} \\
\hline & placing the foam & VA & 5.12 & \\
\hline & labeling & VA & 9.5 & \\
\hline & packing 5 items into the container & VA & 7.98 & \\
\hline & & & & 170.33 \\
\hline
\end{tabular}

Introducing the aforementioned organizational changes enabled to eliminate completely nonvalue adding activities (NVA) in the assembly process. Moreover, introducing work standardization enabled the number of inter operational quality controls to be reduced as they were non-value adding $(R)$. As a result, total time of arm rest assembly has been reduced to $170 \mathrm{sec}$. The introduced changes have made the efficiency indicator LBR increase from 80 to $85 \%$. Reorganizing the process allowed to reduce the number of operators from 10 to 5 . The table 4 shows basic parameters before and after the changes.

Table 4.

Past and present parameters comparison

\begin{tabular}{|l|l|l|}
\hline \multicolumn{1}{|c|}{ Parameter } & \multicolumn{1}{|c|}{ Calculations for the past state } & \multicolumn{1}{c|}{ Calculations for the present state } \\
\hline $\mathrm{T} / \mathrm{T}$ & $40 \mathrm{sec}$. & $40 \mathrm{sec}$. \\
\hline $\mathrm{HC}$ & $319.5 \mathrm{~s} /\left(40 \mathrm{~s}^{\star} 0.85\right)=9.4(\sim 10)$ & $170 \mathrm{~s} /\left(40 \mathrm{~s}^{\star} 0.85\right)=5$ \\
\hline $\mathrm{LBR}$ & $\left(319.5 \mathrm{~s} /\left(40 \mathrm{~s}^{*} 10\right)\right)^{*} 100 \%=80 \%$ & $\left(170 \mathrm{~s} /\left(40 \mathrm{~s}^{\star} 5\right)\right)=85 \%$ \\
\hline NVA & $134 \mathrm{sec}$. & $0 \mathrm{sec}$. \\
\hline
\end{tabular}

\section{SUMMARY}

There are a lot of studies and manuals dealing with Lean Manufacturing. This article, written especially for automotive business management, can be treated as a precious example of Lean Tools used to assess and improve business processes. A lot of automotive manufacturing companies at the very the kick off of the production processes treat client's quality standards as a main criterion to design every single process. After the initial phase, however, possible improvements to increase the efficiency become a challenge. This paper is a perfect example of such a situation. The range of improvements in efficiency of the analyzed process is a proof of that. 


\section{ACKNOWLEDGEMENTS}

The paper is the result of statutory research carried out at the Institute of Production Engineering at the Faculty of Organization and Management of the Silesian University of Technology as part of a project number 13/030/BK_18/0039 called "Development of intelligent production methods as well as work and life environments in the context of production engineering challenges".

\section{REFERENCES}

Książek, D. and Ligarski, M. (2016).The role of the factory production control in the improvement of products and processes. In: A. Gębalska-Kwiecień, ed., Management Systems in Production Engineering. No.4. Gliwice: P.A. Nova S.A., pp. 68-79.

Łopatowska, J. and Jaroński, J. (2016). Doskonalenie przepływu materiału w linii produkcyjnej. [online] Available at: http://www.ptzp.org.pl/files/konferencje/kzz/artyk_pdf_2016/T1/t1_0632.pdf [Accessed 15 May 2018]

Midor, K. (2017).Use of Six Sigma in the production process - case study. In: M.J. Ligarski, ed., Systems supporting production engineering vol. 6 iss. 4. Gliwice: P.A. NOVA pp. 147-152.

Pałucha, K. (2012). World Class Manufacturing model in production management. Archives of Materials Science and Engineering. vol. 58(2), pp. 227-234.

Rother, M., Shook, J., (1998). Learning to see. Value stream mapping to create value and eliminate muda. Brookline: The Lean Enterprise Institute Inc.

Stecuła, K., Tutak, M. and Brodny, J., (2017). Application of chosen elements from Japanese production and maintenance management philosophies in Polish coal mines. In: 17th International Multidisciplinary Scientific GeoConference SGEM. Conference proceedings Vol. 17, Science and technologies in geology, exploration and mining. Iss. 13 - Exploration and mining. Sofia: STEF92 Technology, pp. 93-100.

Velacio.com 2018. Velacio Website. [online] Available at: http://www. velaction.com [Accessed 15 May. 2018].

Wojtaszak, M. and Biały, W. (2013). Measurement system analysis of attribute or continuous data, as a one of the first steps in Lean Six Sigma projects. In: J. Kaźmierczak, ed., Systems supporting production engineering. Gliwice: P.A. NOVA, pp. 144-162

Wolniak, R. and Skotnicka-Zasadzień, B. (2014).The use of value stream mapping to introduction of org $\square$ ni $\square$ tion $\square$ innov tion in industry; Met $\square$ urgii $\square$ vol. 53 iss. 4, pp. 709-712

Womack, J. P., Jones, D.T., Ross, D. (1990).The machines that changed the World. New York: Rawson Associates.

Zasadzień, M. (2015). The effect of implementation maintenance cards in performance of machines in selected production company. Management Systems in Production Engineering No. 4 (20). pp. 225-229. 